\title{
Correction to: Serum biochemistry and haematology in wild and captive bearded seals (Erignathus barbatus) from Svalbard, Norway
}

\author{
Morten Tryland ${ }^{1,2^{*}} \mathbb{D}$, Christian Lydersen ${ }^{3}$, Kit Maureen Kovacs ${ }^{3}$, Espen Rafter ${ }^{4}$ and Stein Istre Thoresen ${ }^{5}$
}

\section{Correction to: Acta Vet Scand (2021) 63:33} https://doi.org/10.1186/s13028-021-00598-8

Following the publication of the original article [1], we were notified of erroneously presented units for red and white blood cells in Table 2 and missing unit for Total T4 in Table 3.

Corrected units are represents in Bold:

Table 2

WBC $\left(\mathbf{1 0}^{9} / \mathrm{L}\right)$

$\operatorname{RBC}\left(\mathbf{1 0}^{12} / \mathrm{L}\right)$

$\mathrm{HGB}(\mathrm{g} / \mathrm{L})$

$\mathrm{HCT}(\mathrm{L} / \mathrm{L})$

$\mathrm{MCV}(\mathrm{fL})$

$\mathrm{MCHC}(\mathrm{g} / \mathrm{L})$

RDW (\%)

$\operatorname{PLT}\left(\mathbf{1 0}^{\mathbf{9}} / \mathrm{L}\right)$

Neutrophils $\left(\mathbf{1 0}^{\mathbf{9}} / \mathrm{L}\right)$

Lymphocytes $\left(\mathbf{1 0}^{\mathbf{9}} / \mathrm{L}\right)$

Monocytes $(\mathbf{1 0} \% / \mathrm{L})$

Eosinophils $\left(\mathbf{1 0}^{\mathbf{9}} / \mathrm{L}\right)$

Basophils $\left(\mathbf{1 0}^{\mathbf{9}} / \mathrm{L}\right)$
Table 3

Total T4 (nmol/L)

\begin{abstract}
Author details
'Department of Arctic and Marine Biology, UiT The Arctic University of Norway, Framstredet 39, 9037 Troms $\varnothing$, Norway. ${ }^{2}$ Department of Forestry and Wildlife Management, Inland Norway University of Applied Sciences, 2480 Koppang, Norway. ${ }^{3}$ Norwegian Polar Institute, Fram Centre, 9296 Troms $\varnothing$, Norway. ${ }^{4}$ Polaria, Hjalmar Johansens gate 12, 2007 Tromsø, Norway. ${ }^{5}$ Faculty of Veterinary Medicine, Norwegian University of Life Sciences, 1432 Ås, Norway.
\end{abstract}

Published online: 08 September 2021

\begin{abstract}
Reference
1. M Tryland C Lydersen KM Kovacs E Rafter 2021 Serum biochemistry and haematology in wild and captive bearded seals (Erignathus barbatus) from Svalbard, Norway Acta Vet Scand 6333 https://doi.org/10.1186/ s13028-021-00598-8
\end{abstract}

\section{Publisher's Note}

Springer Nature remains neutral with regard to jurisdictional claims in published maps and institutional affiliations. to the material. If material is not included in the article's Creative Commons licence and your intended use is not permitted by statutory regulation or exceeds the permitted use, you will need to obtain permission directly from the copyright holder. To view a copy of this licence, visit http://creativecommons.org/licenses/by/4.0/. The Creative Commons Public Domain Dedication waiver (http://creativeco mmons.org/publicdomain/zero/1.0/) applies to the data made available in this article, unless otherwise stated in a credit line to the data. 